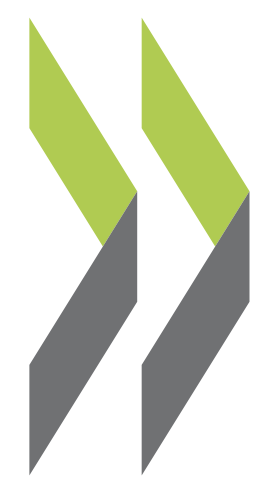

OECD Social, Employment and Migration Working Papers No. 169

Working and learning: A diversity of patterns

\title{
Glenda Quintini
}




\section{WORKING AND LEARNING: A DIVERSITY OF PATTERNS}

Authorised for publication by Stefano Scarpetta, Director,

Directorate for Employment, Labour and Social Affairs 


\title{
DIRECTORATE FOR EMPLOYMENT, LABOUR AND SOCIAL AFFAIRS
}

$\underline{\text { www.oecd.org/els }}$

\section{OECD SOCIAL, EMPLOYMENT AND MIGRATION WORKING PAPERS}

\author{
www.oecd.org/els/workingpapers
}

OECD Working Papers should not be reported as representing the official views of the OECD or of its member countries. The opinions expressed and arguments employed are those of the author(s).

Working Papers describe preliminary results or research in progress by the author(s) and are published to stimulate discussion on a broad range of issues on which the OECD works. Comments on Working Papers are welcomed, and may be sent to the Directorate for Employment, Labour and Social Affairs OECD, 2 rue André-Pascal, 75775 Paris Cedex 16, France.

This series is designed to make available to a wider readership selected labour market, social policy and migration studies prepared for use within the OECD. Authorship is usually collective, but principal writers are named. The papers are generally available only in their original language - English or French with a summary in the other.

This document and any map included herein are without prejudice to the status of or sovereignty over any territory, to the delimitation of international frontiers and boundaries and to the name of any territory, city or area.

\author{
Applications for permission to reproduce or translate \\ all or part of this material should be made to: \\ Head of Publications Service \\ OECD \\ 2, rue André-Pascal \\ 75775 Paris, CEDEX 16 \\ France
}

Copyright OECD 2015 


\section{ACKNOWLEDGEMENTS}

Glenda Quintini is a Senior Economist in the Directorate for Employment, Labour and Social Affairs, Division for Employment Analysis and Policy.

The author is grateful to Mark Keese and Simon Fields for their useful feedback and suggestions. 


\section{SUMMARY}

The combination of work and study has been hailed as crucial to ensure that youth develop the skills required on the labour market so that transitions from school to work are shorter and smoother. This paper fills an important gap in availability of internationally-comparable data. Using the 2012 Survey of Adult Skills (PIAAC), it draws a comprehensive picture of work and study in 23 countries/regions. Crucially, it decomposes the total share of working students by the context in which they work (VET, apprenticeships or private arrangements) and assesses the link between field of study and students' work. The paper also assesses how the skills of students are used in the workplace compared to other workers and identifies the socio-demographic factors and the labour market institutions that increase the likelihood of work and study. Finally, while it is not possible to examine the relationship between work and study and future labour market outcomes at the individual level, some aggregate correlations are unveiled.

\section{RESUMÉ}

La plupart des études sur le chômage des jeunes attribuent une importance clé au cumul emploi/études pour raccourcir et améliorer les transitions de l'école à l'emploi et cela sur la base du fait qu'il permet aux jeunes d'acquérir les compétences demandées sur le marché du travail. Ce papier remplit le manque de données comparables à niveau international sur ce sujet. Grâce à l'Enquête sur les Compétences des Adultes (PIAAC), il permet d'évaluer l'étendue du cumul emploi/études dans 23 pays ou régions. Plus particulièrement, il permet d'identifier ces composantes principales (la formation professionnelle en alternance, l'apprentissage ou le travail des étudiants en dehors de ces programmes) et d'évaluer le lien entre le domaine d'étude et la nature du travail étudiant. Le papier étudie aussi comment les compétences des étudiants travailleurs sont utilisées aux seins des entreprises par rapport à celles des autres travailleurs et identifie les caractéristiques sociodémographiques ainsi que les institutions du marché du travail qui sont associées avec une probabilité accrue de cumul emploi/études. Pour finir, même s'il n'est pas possible d'examiner la relation entre le statut en termes de cumul emploi/études de chaque individu et sa réussite sur le marché du travail une fois les études terminées, le papier décèle quelques relations agrégées entre l'incidence du cumul emploi/études et le taux de chômage des jeunes sortis du système scolaire. 
TABLE OF CONTENTS

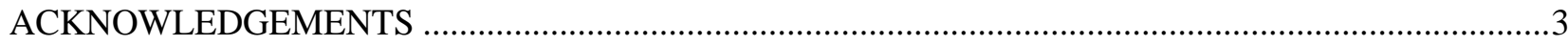

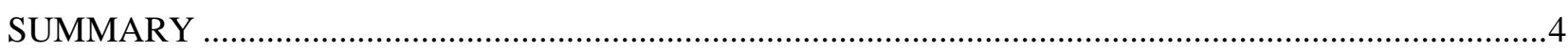

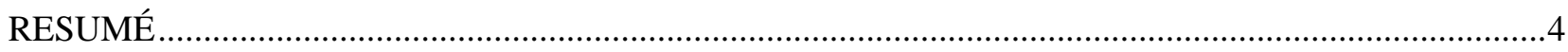

INTRODUCTION

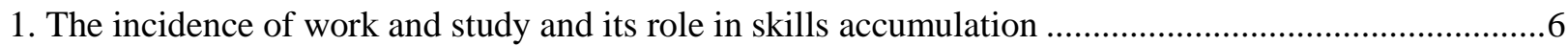

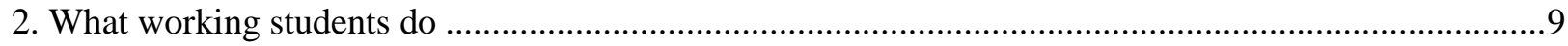

3. Individual determinants of work and study choices..........................................................................13

4. Work and study, information processing skills and aggregate labour market outcomes ......................17

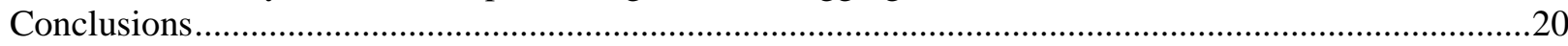

ANNEX A.1. Coding of ISCO-08 3-digit occupation classification to fields

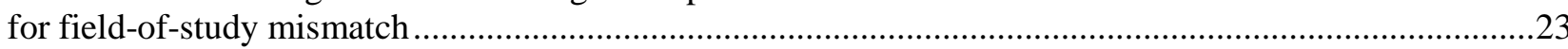

\section{Tables}

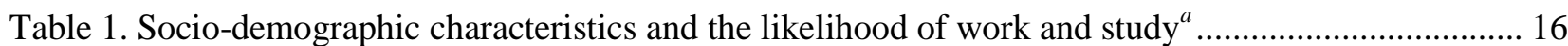

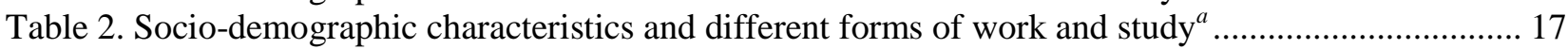

\section{Figures}

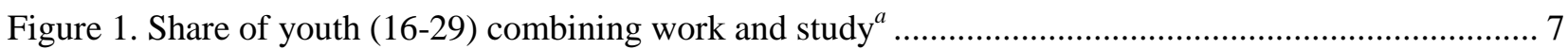

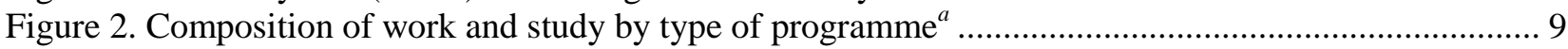

Figure 3. Link between students' field of study and area of work while studying ${ }^{a}$.................................. 10

Figure 4. Correlation between field-of-study mismatch in the labour market

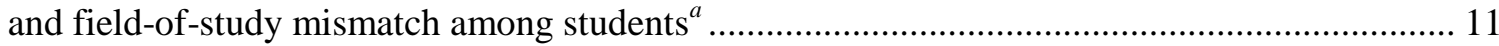

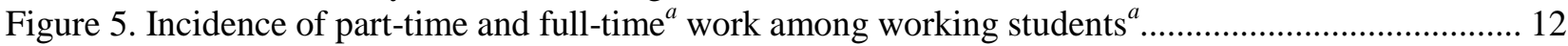

Figure 6. Difference in skill use between working students and other workers ......................................... 13

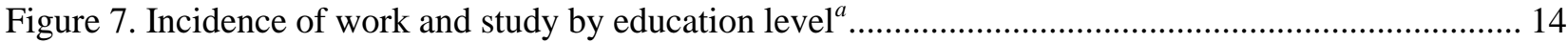

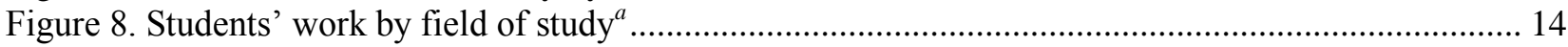

Figure 9. Literacy proficiency scores by work and study status.......................................................... 18

Figure 10. Correlation between the incidence of work and study and youth unemployment ${ }^{a} \ldots \ldots \ldots \ldots \ldots \ldots \ldots . . . . . . . . .20$ 


\section{INTRODUCTION}

1. The combination of work and study has been hailed as crucial to ensure that youth develop the skills required on the labour market so that transitions from school to work are shorter and smoother. As a result, in the current context of record high unemployment rates, many governments have set out to encourage learning on the job, particularly when it comes as part of certified programmes such as vocational education and training pathways (VET) or apprenticeships. Despite this central role in current policy thinking, comparative statistics on work and study are hard to come by and information is patchy at best when it comes to the context in which most students work - crucially, whether there is a (formal or informal) link between their schooling and their job.

2. This paper draws a comprehensive picture of work and study in 23 countries/regions participating in the 2012 Survey of Adult Skills (PIAAC). It decomposes the total share of students who work by the context in which they work (VET, apprenticeships or private arrangements) and assesses the link between field of study and students' work (Sections 1 and 2). The paper also identifies the socio-demographic factors, the characteristics of the education system and the labour market institutions that increase the likelihood of work and study (Section 3). Finally, while it is not possible to examine the relationship between work and study and future labour market outcomes at the individual level, some aggregate correlations are unveiled (Section 4).

\section{The incidence of work and study and its role in skills accumulation}

3. The Survey of Adult skills provides unique comparable cross-country information on the incidence and composition of work and study. Combining information on student and work status, educational pathway and apprenticeship status (see Box 1), the survey suggests that 39\% of 16-29 year-old students worked in 2012 (Figure 1). However, this average hides major differences across countries: the combination or work and study is found to be most common in Anglo-Saxon countries as well as countries with a long tradition of apprenticeships where more than half of students work; it is least common in the Czech Republic, Flanders and Italy where fewer than $20 \%$ of students work. 
Figure 1. Share of youth (16-29) combining work and study ${ }^{a}$

Percentages of all students ${ }^{b}$

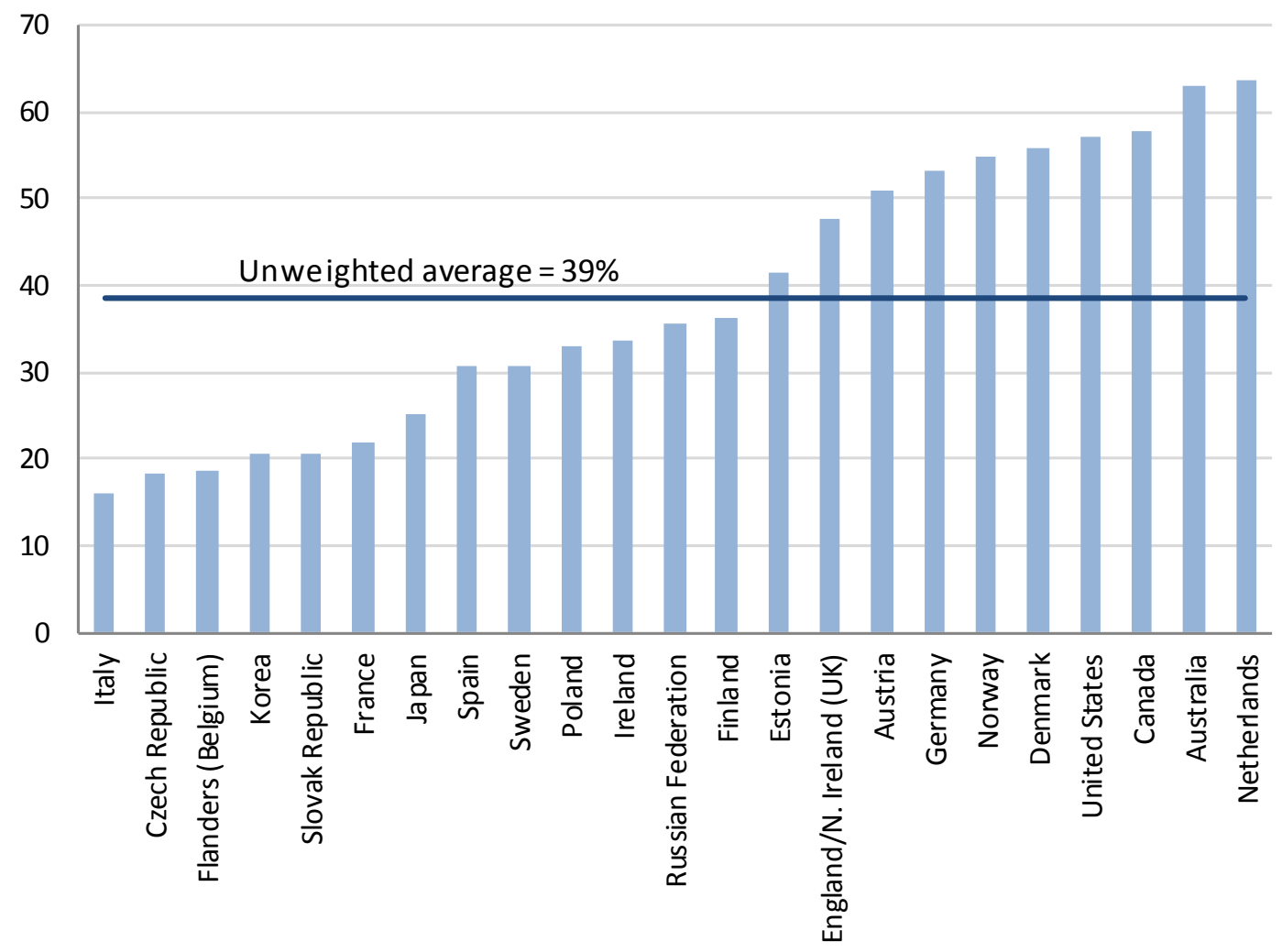

a) All apprentices - by labour market status and/or by contract type - are counted as combining work and study, irrespective of what they report. Indeed, some apprentices classify themselves as students while others see themselves as simply working.

b) Apprentices who do report "only work" as a labour force status are added to the total of student. This is done for consistency with their inclusion among youth who are working and studying.

Source: OECD calculations based on Survey of Adult Skills (PIAAC) (2012).

\section{Box 1. Counting working students using PIAAC}

\section{Baseline variable}

The Survey of Adult Skills (PIAAC) includes a derived variable summarising information on labour market and education status (EDWORK). This variable is the starting point of the definition of work and study used in this paper, with everybody aged 16-29 and reporting to be working and in education (EDWORK=2) counted as a working student.

\section{Treatment of apprentices}

This paper assumes that all apprentices combine work and study, irrespective of what their answer to the labour force and education status questions are $-i$.e. irrespective of whether EDWORK=2. To do so, a first step is to identify all apprentices. Two questions can be used for this purpose: C_q07 which summarises the current status of the respondent and includes "apprenticeship or internship" as an option; and D_q09 which enquires about the type of contract that a person has and includes "an apprenticeship or other training scheme" as an option. Those reporting themselves as being "apprentices" in both or either of these questions are counted as apprentices. " A second step consist in identifying apprentices that are not reporting themselves as working and those not reporting themselves as studying. 


\section{Box 1. Counting working students using PIAAC (cont.)}

These will not be included in the baseline definition of work and study, based on the EDWORK variable, hence need to be added to the total of working students. In addition, apprentices who do not report being students also need to be added to the total of 16-29-year olds who are studying which represents the reference group - i.e. the denominator - to calculate the incidence of work and study. Finally, youth who report being apprentices and on a vocational education and training are treated as apprentices only to avoid double counting.

Isolating working students in Vocational Education and Training programmes

Whether the person is currently studying towards a Vocational Education and Training (VET) qualification is defined using the same correspondence employed for VET status in the highest educational qualification of the respondent (available upon request). Because VET courses can be entirely class-based, contrary to the treatment of apprentices, only VET students declaring that they are working and studying are included in the analysis for this paper. It is noteworthy that VET status is only available at educational levels where the choice between academic or vocational education is possible. As a result, in most countries, VET status is only available for students in upper secondary education or higher. However, some exceptions exist for countries where VET education is available in lower secondary education.

a) Some respondents will declare to be working and then to have an apprenticeship contract $\left(C \_q 07=1\right.$ or 2 ; and $D$ _q09=4) while others will simply say they are apprentices $\left(C_{-}\right.$q07 $\left.=5\right)$. In both cases, the respondent is counted as an apprentice and as combining work and study.

4. Apprenticeships account for about $50 \%$ of all work and study in Germany and France, about $40 \%$ in Austria and Italy, 20\% in Denmark, Flanders (Belgium), the Netherlands and Spain while they represent less than $10 \%$ of the total in most other countries (Figure 2). VET programmes also account for a large portion of work and study in some countries, exceeding $20 \%$ in the Czech Republic, Denmark, Norway and Poland. However, many youth who combine work and study are neither apprentices nor studying towards a VET programme. This is particularly the case in England/N. Ireland, Japan, Korea, Sweden and the United States where this group accounts for about $90 \%$ of work and study. ${ }^{1}$

1. A further split (not shown here) would show that most youth working outside VET or apprenticeship programmes are in tertiary education. 
Figure 2. Composition of work and study by type of programme ${ }^{a}$

Percentages of all youth (16-29) combining work and study ${ }^{b}$

VET $\square$ Apprenticeships $\square$ Other

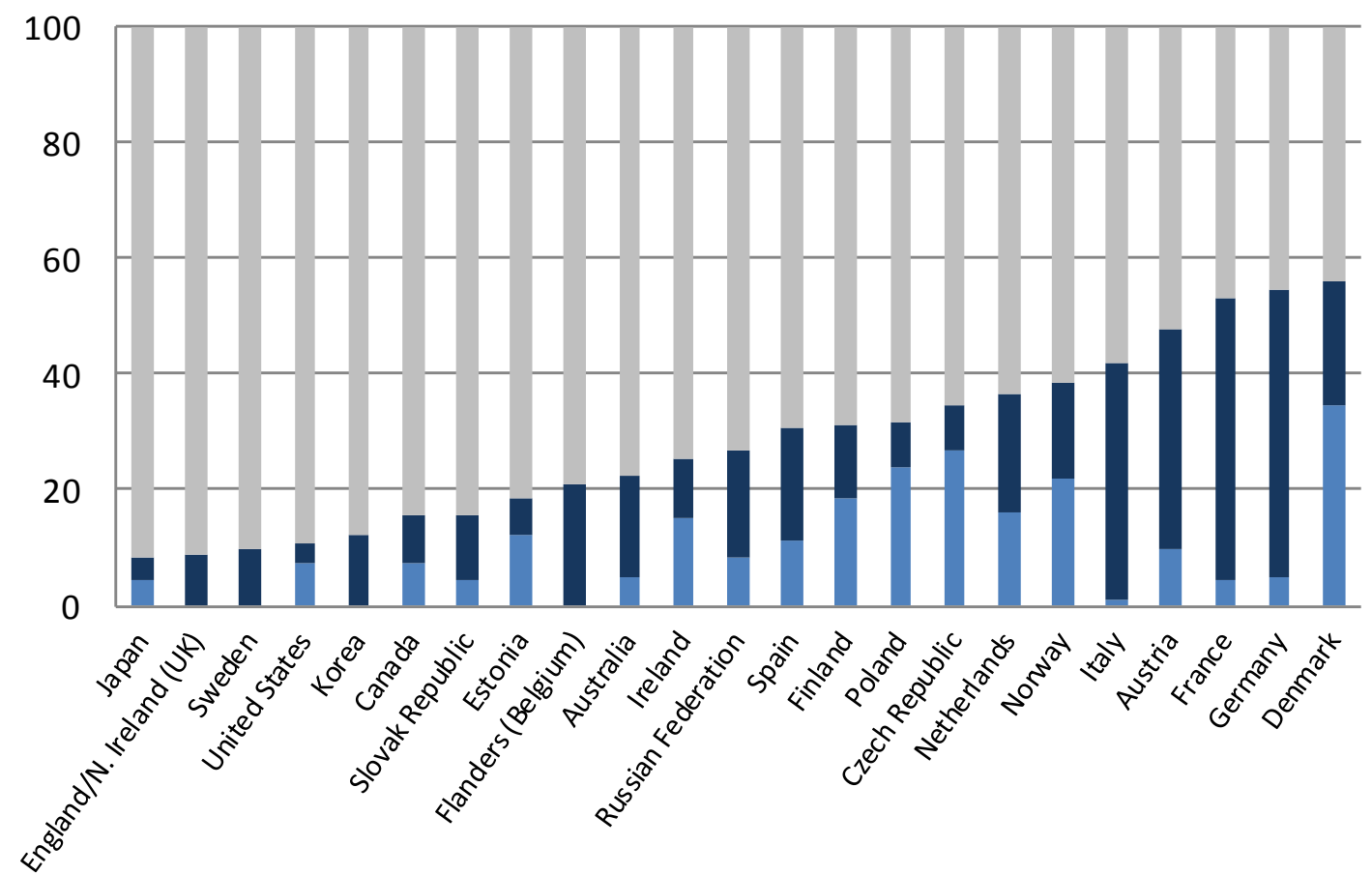

a) Information to identify VET programmes is missing in the following countries: Flanders (Belgium), England/N.Ireland (UK) and Sweden. Values for Denmark and Italy represent a lower bound as the distinction between VET and not is not available at all relevant ISCED levels.

b) The categories are mutually exclusive. Hence VET refers to all students in VET programmes who do not report being apprentices. All apprentices - by labour market status and/or by contract type - are counted as combining work and study, irrespective of what they report. Indeed, some apprentices classify themselves as students while others see themselves as simply working.

Source: OECD calculations based on Survey of Adult Skills (PIAAC) (2012).

\section{What working students do}

5. The Survey of Adult Skills shows that countries differ significantly in the extent to which students get jobs in their field of not (Figure 3). This is an area where cultural differences are likely to play a major role, both on the supply and the demand side. On the supply side, countries differ in the extent to which students engage in work outside structured internships and apprenticeships or outside vocational education work-based practice. This is very uncommon in continental European countries where a study first, work later logic applies to the majority of students while it is more common in Anglo-Saxon countries where students' jobs - evening, summer, week-end jobs - are commonplace. On the demand side, employers vary in the extent to which curriculum activities that are not related to a candidate's studies are valued. In some countries, employers are open to all work activities that are susceptible to teach young people the generic skills required at work - time-keeping, team-work, self-organisation, presentation skills etc. In others, generally those where credentials play a key role, employers are focused on work experience that is specific to the content of the job they are recruiting for. It goes without saying that these two elements - supply and demand - are related, with students engaging more in work outside their field in countries where they know these activities will be valued by employers. 
Figure 3. Link between students' field of study and area of work while studying ${ }^{a}$

Percentages - working students decomposition based on match between field of study and area of work

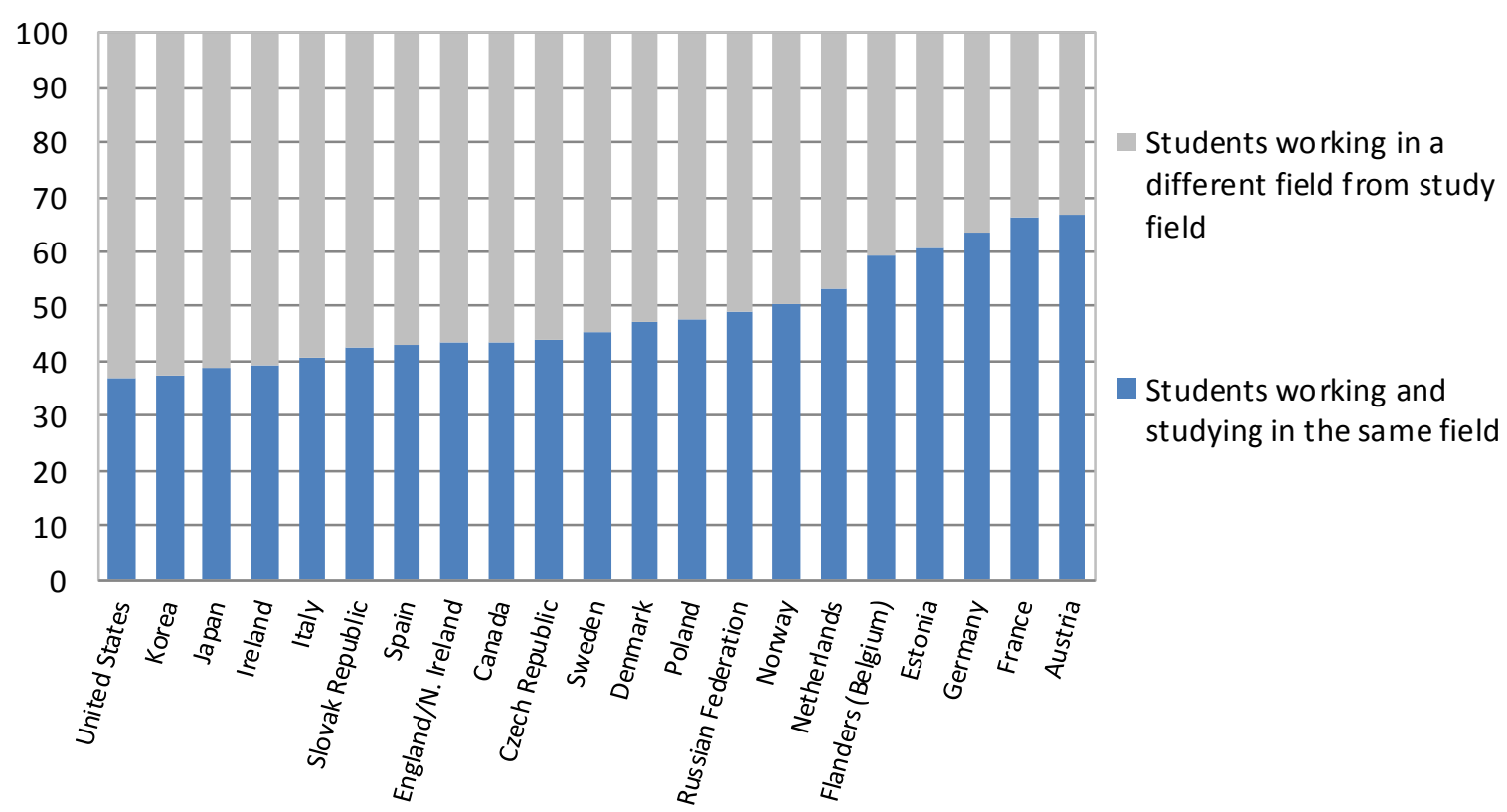

a) Field of study mismatch is derived based on an a-priori judgement of what occupations (at ISCO 3-digit level) are to be considered a good match for each field of study. The mapping is largely based on Wolbers (2003) and is presented in Annex A.1.

Source: OECD calculations based on Survey of Adult Skills (PIAAC) (2012).

6. Further strengthening the arguments presented above is the correlation between the incidence of field-of-study mismatch in the labour market and its incidence among youth combining work and study (Figure 4). Also, at the individual level, while students are about 14 percentage points more likely to be mismatched by field of study than fellow workers who are not studying, this difference disappears after controlling for individual and job characteristics. 

among students $^{a}$

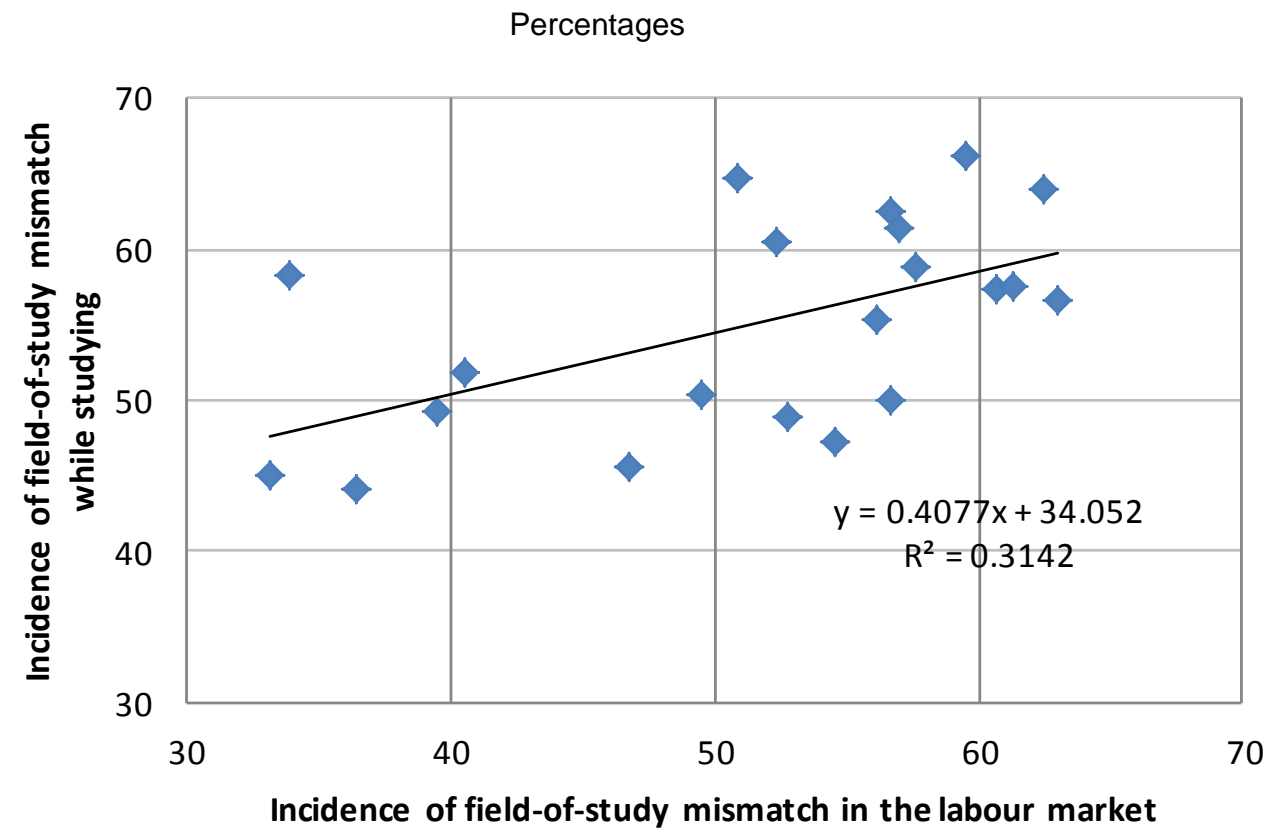

a) Field of study mismatch is derived based on an a-priori judgement of what occupations (at ISCO 3-digit level) are to be considered a good match for each field of study. The mapping is largely based on Wolbers (2003) and is presented in Annex A.1.

Source: OECD calculations based on Survey of Adult Skills (PIAAC) (2012).

7. The extent to which students work part-time or full-time also varies significantly across countries (Figure 5). Only $20 \%$ of students worked full-time in Japan in 2012 while this was the case for about $70 \%$ of students in France. The cross-country differences do not appear to be related to the incidence of part-time in the country but rather to the nature of work and study. For instance, on average $73 \%$ of apprentices report working full-time compared with just 49\% of VET students and $40 \%$ of students working under other arrangements. This explains the high incidence of full-time student work in countries where apprentices represent the majority of working students, notably France, Germany, Austria and Italy. On the other hand, the high incidence of full-time work overall - among apprentices but also among students in VET and other working arrangements - explains the high overall incidence in Estonia, Poland, the Russian Federation and the Czech Republic. Finally, the actual number of hours worked varies markedly for both part-timers and full-timers. While part-time work is defined as working less than 30 hours per week, for students it translates into just 13 hours on average, compared to an overall average of just over 16 hours per week. In fact, students employed part-time work between 10 hours a week in Denmark and 15 hours a week in Estonia and the United States. Similarly, while full-time work is defined as work at or above 30 hours a week, full-time student work translates into an average of 41 hours compared with 44 for workers more generally - and ranges between 37 hours a week on average in France and 44 hours a week in the Russian Federation. 
Figure 5. Incidence of part-time and full-time ${ }^{a}$ work among working students ${ }^{a}$

Percentages

Part-time work $\square$ Full-time work $\Delta$ Overall incidence of part-time work in the country

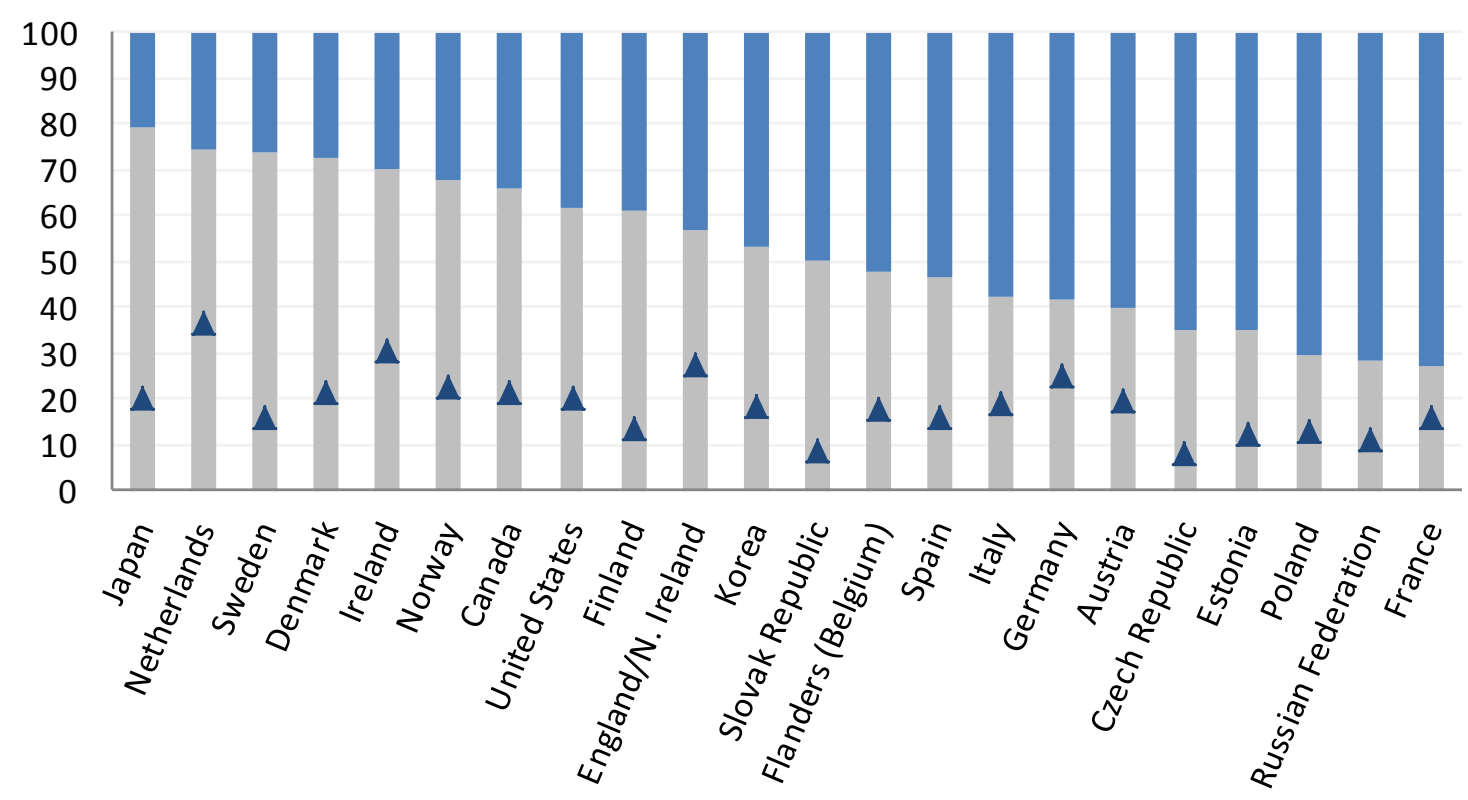

a) Full-time is defined as working 30 hours or more.

Source: OECD calculations based on Survey of Adult Skills (PIAAC) (2012).

8. The Survey of Adult Skills also provides information on the use of information processing as well as generic skills at work. Questions on the tasks carried out at work can be aggregated to generate 12 indices of skill use, ranging from " $1=$ never" to " $5=$ every day". ${ }^{2}$ Figure 6 reports the row difference in the use of skills at work between working students and regular workers and shows how this difference is explained by individual - gender, educational attainment and proficiency in literacy and numeracy - and job characteristics - hours worked, contract type, firm size, industry and occupation. The row differences in skill use are fairly large, particularly for problem solving, writing, self-organising skills and ICT, with all four of these skills being used less frequently by working students. Controlling for individual characteristics reduces the differences but in most cases it is the types of jobs held - more specifically, the fact the students are more likely to work part-time - that explain most of the difference between students and their co-workers.

9. Indeed, although statically significant for all skills apart from dexterity, the fully-adjusted differences tend to be small - noticeably smaller than the differences across occupation or industry, which explain most of the variation in skills use across workers. The largest differences in skills use between working students and their counterpart who are only working are found in problem solving skills - used less by working students - and learning skills - used most by working students. In both cases, the absolute value of the skills use different is approximately 0.15 points, still rather small in scales that range from 1 to 5 and have a standard deviation of 1.3 and 1 respectively. These findings suggest that, all else being equal, students are given the opportunity to use - hence, develop - their skills at work in line with job requirements and this applies both to generic skills and information-processing ones.

2. See Quintini (2014) for an explanation of how these indices are derived. 
Figure 6. Difference in skill use between working students and other workers

Row and adjusted differences ${ }^{a}$, in indices ranging from 1 (never use the skill) to 5 (use the skill every day) ${ }^{b}$

Raw difference $\backsim$ Net of individual characteristics only $\square$ Net of individual and job characteristics

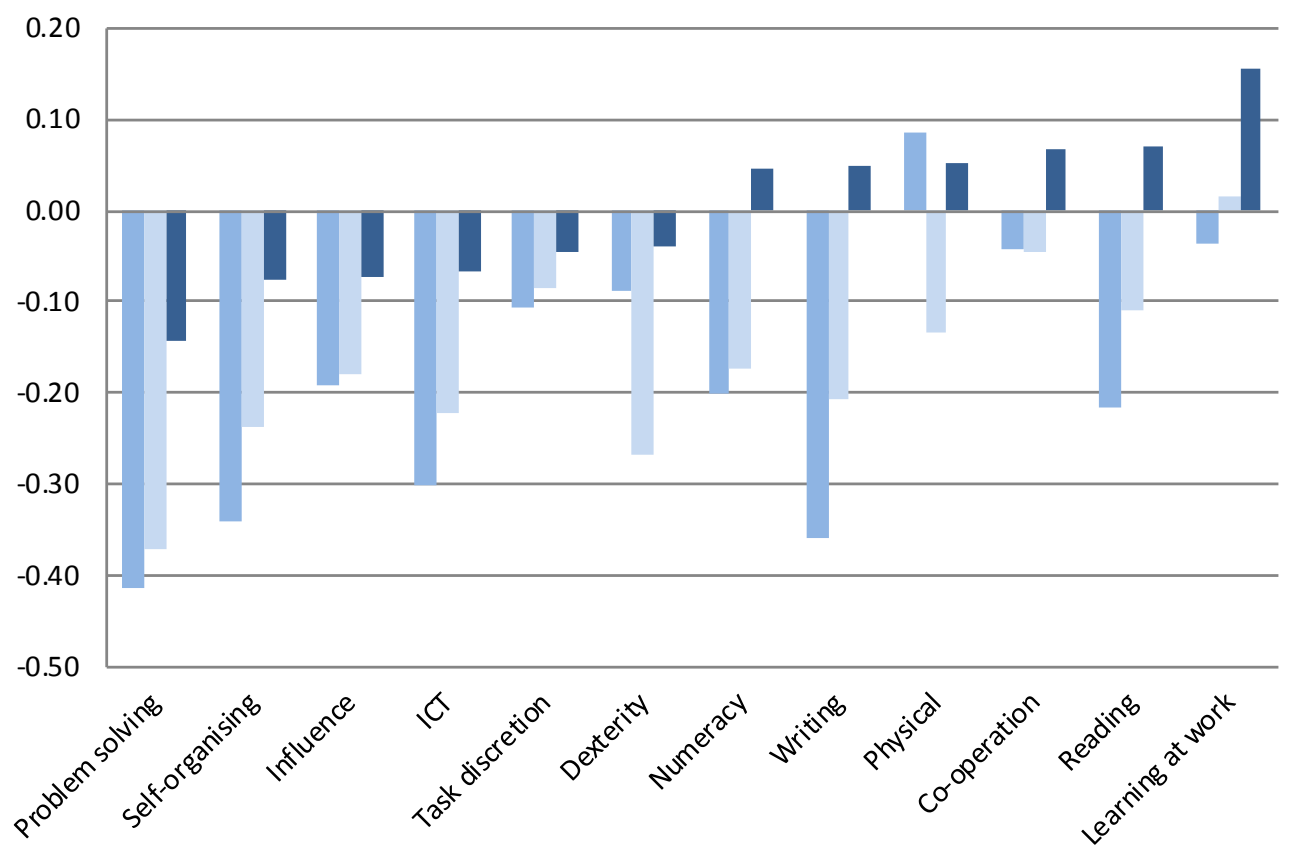

a) Pooled OLS regressions including country dummies, gender, educational attainment and proficiency in literacy and numeracy, hours worked, contract type, firm size, industry and occupation along with a dummy indicating whether the worker was a student and/or apprentice.

b) See Quintini (2014) for a description of how the skill use indices are derived.

Source: OECD calculations based on Survey of Adult Skills (PIAAC) (2012).

\section{Individual determinants of work and study choices}

10. Youth studying towards a tertiary qualification are more likely to work than youth who are still in high school in most countries, with the exception of countries where apprenticeships play a large role in upper secondary education (Figure 7). Male and female students have the about the same likelihood of working on average and in most countries (not shown). Differences of more than five percentage points are observed in Austria and the Russian Federation (in favour of male students) as well as in Ireland and Norway (in favour of women). Finally, differences across fields of study are less marked for tertiary students than for upper-secondary ones. However, irrespective of the education level attended, students whose current field of study is Health and welfare, Teacher training and education science or Humanities, languages and arts are the most likely to work (Figure 8). 
Figure 7. Incidence of work and study by education level ${ }^{a}$

Percentages

Upper secondary $\quad$ Tertiary

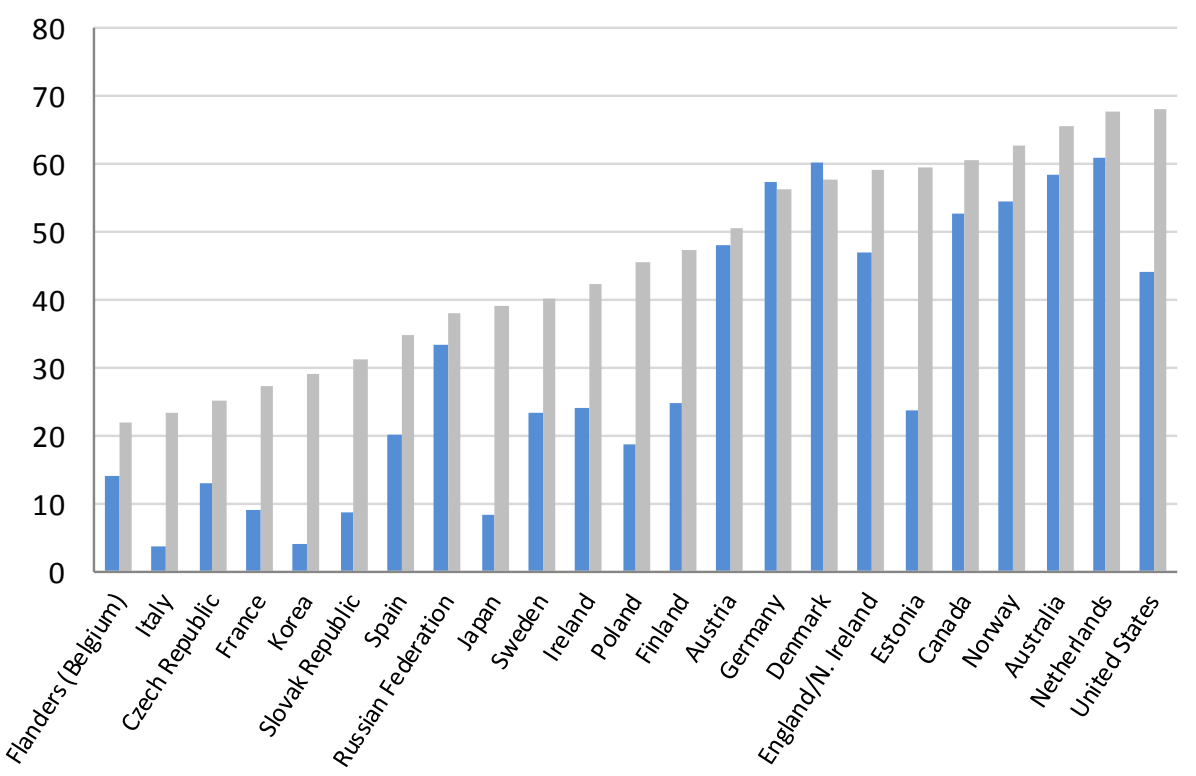

a) This is the level of education that each young person (16-29) is currently studying for.

Source: OECD calculations based on Survey of Adult Skills (PIAAC) (2012).

Figure 8. Students' work by field of study ${ }^{a}$

Working students as a percentage of students at each education level

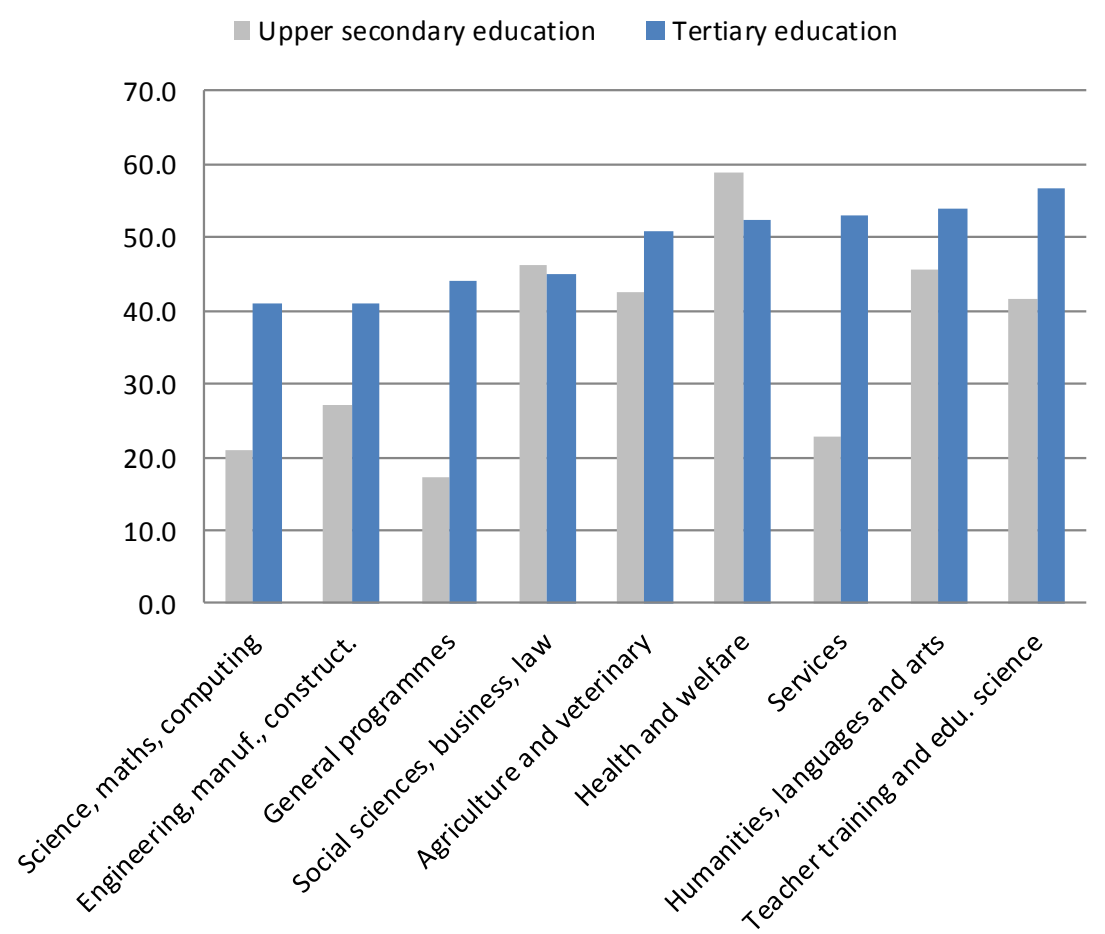

Source: OECD calculations based on Survey of Adult Skills (PIAAC) (2012). 
11. These findings are supported by Table 1 reporting marginal effects of socio-demographic characteristics on the likelihood of working and studying but some interesting interactions emerge. For instance, the difference in the likelihood of students' work by education qualification appears to be driven by the general nature of programmes in lower secondary education. In fact, once field of study is controlled for, the likelihood of working and studying declines with educational attainment. Interestingly, students in vocational education and training programmes are less likely to work and study than their counterparts, all else being equal. Finally, older youth are more likely to work and study while higher literacy is associated with a lower likelihood to combine studies and work.

12. Model 3 of Table 1 extends the analysis to tentatively identify labour market features that may affect the likelihood of work among students. Given that the incidence of vet and apprenticeships is more likely to be related to specific features of these programmes rather than labour market characteristics, the analysis is limited to the likelihood of working outside vet or apprenticeship schemes. The strictness of employment protection legislation and difficulty of use of temporary contracts both negatively affect the probability that a student work, although the latter variable is not statistically significant. This could reflect the reluctance of employers to hire a student when firing is complex and/or costly, at least in the formal labour market. Secondly and unsurprisingly, the incidence of part-time work in the country is positively associated with students' likelihood of working as part-time employment no doubt allows better reconciling work and study. The share of public sector employment is also positively related to the likelihood of work and study while a negative correlation is found with the ratio of the minimum to median wage in the country. In fact, a high minimum wage - relative to median wages in the country - may make it too costly for employers to hire inexperienced students. ${ }^{3}$

13. Because work and study can take different forms, as highlighted in Figure 2, Table 2 summarises the results from a multinomial logit regression allowing to disentangle the link between different socio-demographic characteristics and the likelihood of VET, apprenticeship training, work outside these two programmes or study only. Compared to teenagers, young adults - aged 20-29 - are more likely to work within VET or apprenticeship programmes rather than not work at all. The likelihood of work and study outside VET or apprenticeship programmes as compared to studying only appears to be influenced (positively) only by the enrolment in a tertiary degree while tertiary students are least likely to work within VET or apprenticeship schemes. Compared to general programmes, most specific fields influence the likelihood of working within VET or apprenticeships both relative to not working and relative to working outside these formalised schemes. Finally, parental educational attainment is found to influence (negatively) the likelihood of working within VET programmes as opposed to either studying only or working outside VET or apprenticeships.

3. In fact, the coefficient on the minimum-to-median wage ratio is likely to reflect both supply and demand factors. On the demand side - which appears to prevail - a high minimum wage means a high cost for employers when hiring students. On the supply side, a high minimum wage would provide an incentive for students to work by increasing the opportunity cost of studying only. 
Table 1. Socio-demographic characteristics and the likelihood of work and study ${ }^{a}$

Marginal effects from probit regressions pooling all countries for which data is available

Dependent variable - likelihood of:

Work and study Work and study $\begin{gathered}\text { Work and study } \\ \text { outside vet and } \\ \text { apprenticeships }\end{gathered}$

\begin{tabular}{|c|c|c|c|}
\hline Explanatory variables & Model 1 & Model 2 & Model 3 \\
\hline \multicolumn{4}{|l|}{ Ref: Men } \\
\hline Women & -0.020 & -0.004 & 0.000 \\
\hline \multicolumn{4}{|l|}{ Ref: youth aged 16-19 } \\
\hline youth aged $20-29$ & $0.259 * * *$ & $0.245^{* * *}$ & $0.139 * * *$ \\
\hline \multicolumn{4}{|l|}{ Ref: studying below upper secondary education } \\
\hline in Upper secondary education & $0.092^{* *}$ & $-0.197^{\star \star \star}$ & -0.056 \\
\hline in Tertiary education & $0.177^{* * *}$ & $-0.222^{* * *}$ & $0.289 * * *$ \\
\hline \multicolumn{4}{|l|}{ Ref: not in Vocational Education and Training } \\
\hline in Vocational Education and Training programme & -0.093 & $-0.067 * *$ & \\
\hline Standardised literacy score & -0.026 * & $-0.043^{* * *}$ & -0.022 \\
\hline \multicolumn{4}{|l|}{ Ref: Born in the country } \\
\hline Foreign born & -0.068 * & -0.062 & -0.016 \\
\hline \multicolumn{4}{|l|}{ Ref: Neither parent has attained upper secondary education } \\
\hline At least one parent has attained secondary education & 0.019 & 0.034 & 0.039 \\
\hline At least one parent has attained tertiary education & -0.024 & -0.013 & 0.018 \\
\hline \multicolumn{4}{|l|}{ Ref: in General programme } \\
\hline Teacher training and education science & & $0.166^{* * *}$ & 0.008 \\
\hline Humanities, languages and arts & & $0.125^{* * *}$ & -0.029 \\
\hline Social Sciences, Business and Law & & $0.193^{* * *}$ & -0.002 \\
\hline Science, Mathematics and Computing & & $0.146 * * \star$ & -0.008 \\
\hline Engineering, Manufacturing and Construction & & $0.176^{\star \star \star}$ & $-0.085 *$ \\
\hline Agriculture and Veterinary & & 0.226 *** & 0.007 \\
\hline Health and Welfare & & $0.187^{* * *}$ & -0.037 \\
\hline Services & & $0.202^{* * *}$ & -0.090 \\
\hline \multicolumn{4}{|l|}{ Institutional variables } \\
\hline Protection against individual and collective dismissals & & & $-0.085^{* * *}$ \\
\hline Difficulty of use of temporary contracts & & & -0.022 \\
\hline Share of employment in the public sector & & & $0.024^{* * *}$ \\
\hline Incidence of part-time in the country & & & $0.023^{* * *}$ \\
\hline Minimum-to-median w age ratio & & & -1.282 *** \\
\hline Country dummies & yes & yes & no \\
\hline
\end{tabular}

a) Results from a pooled probit model.

Source: OECD calculations based on Survey of Adult Skills (PIAAC) (2012). 
Table 2. Socio-demographic characteristics and different forms of work and study ${ }^{a}$

Odds comparing:

$\begin{array}{lll}\text { Status } 1 \longrightarrow \text { Apprentice } & \text { VET } \begin{array}{c}\text { Other work Apprentice } \\ \text { and study }\end{array} \\ \text { Status } 2 \longrightarrow \begin{array}{c}\text { Other work } \\ \text { and study }\end{array} \text { Other work } \\ \text { and study Study only Study only Study only }\end{array}$

Ref: youth aged 16-19

youth aged 20-29

Ref: studying below upper secondary education

in Upper secondary education

in Tertiary education

Ref: Born in the country

Foreign born

Ref: Neither parent has attained upper secondary education

At least one parent has attained secondary education

At least one parent has attained tertiary education

Ref: in General programme

Teacher training and education science

Humanities, languages and arts

Social Sciences, Business and Law

Science, Mathematics and Computing

Engineering, Manufacturing and Construction

Agriculture and Veterinary

Health and Welfare

Services

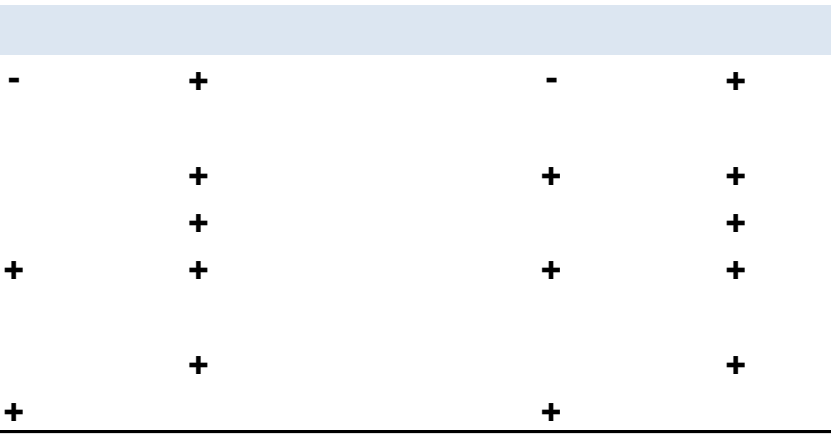

a) Results from a pooled multinomial logit model, including country dummies, gender and standardised literacy scores in addition to the variables shown. Only the sign of statistically significant variables is shown.

Source: OECD calculations based on Survey of Adult Skills (PIAAC) (2012).

\section{Work and study, information processing skills and aggregate labour market outcomes}

14. Several analysts have looked into the relationship between the combination of work and study, labour market outcomes and educational outcomes (see Box 2). Although having worked while studying is generally considered beneficial when entering the labour market, some have found that it delays graduation and/or has a negative impact on marks. While the Survey of Adult skills can only unveil correlations between work and study and proficiency, it is does provide some insights into this issue.

15. On average, across countries and after controlling for education level and other individual characteristics, youth who combine work and study score about 5 points higher in literacy than those who study only. However, the magnitude of the difference and the direction vary across countries and by type of work and study experience (Figure 9). The highest scores are observed among youth who work and study outside formalised programmes such as VET and apprenticeships, while students on VET or apprenticeship programmes tend to score less than students who do not work. On the other hand, no sizeable differences in proficiency are observed based on hours worked, after controlling for individual characteristics, education level and type of work and study experience. 
Figure 9. Literacy proficiency scores by work and study status

Adjusted scores to account for differences in education, gender, socio-economic and migration backgrounds (youth, $16-29)^{a}$

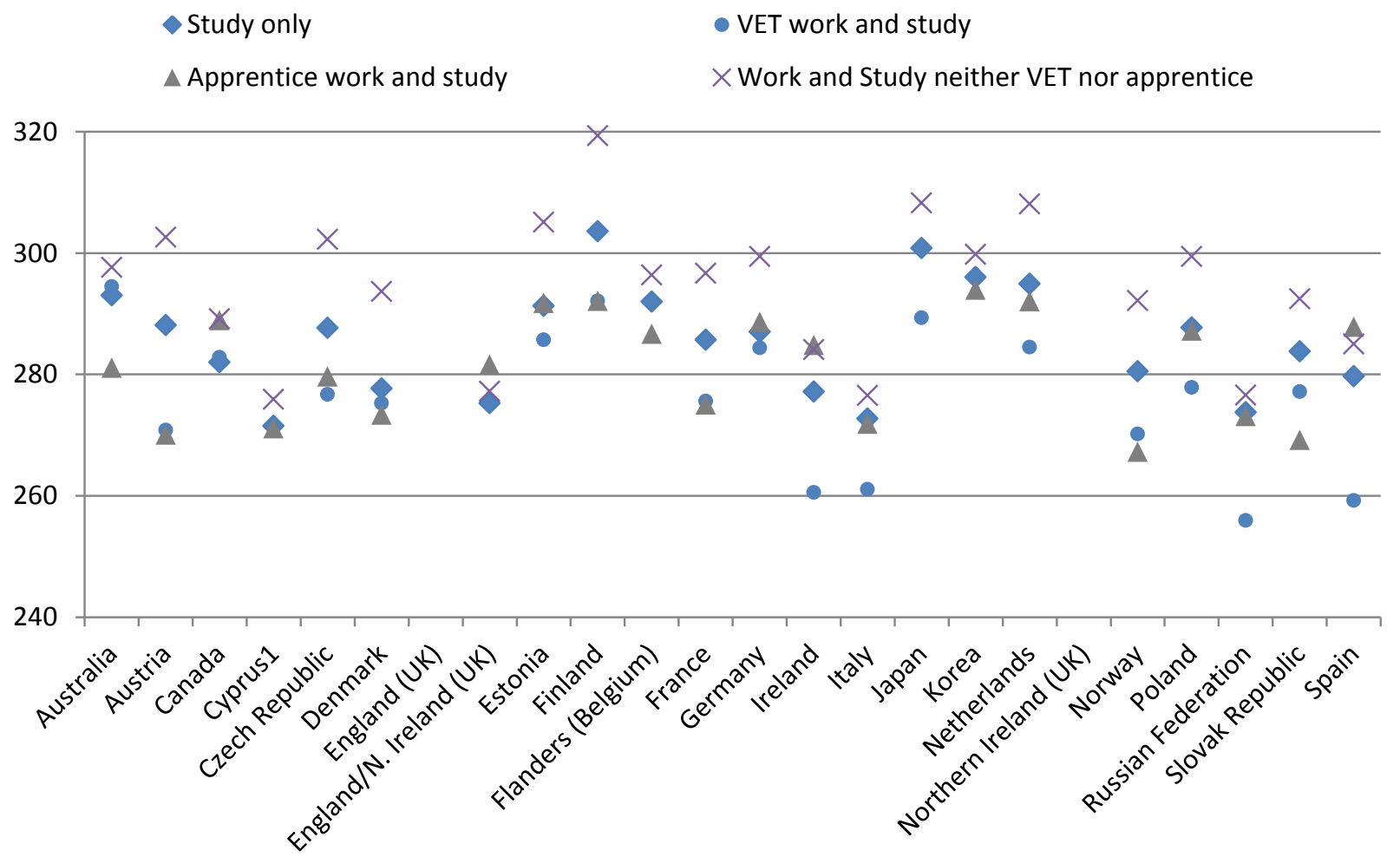

a) Adjusted values are predicted scores from OLS regressions of literacy scores on the following controls: gender, education level towards which the young person is studying, education level of parents, country of birth, language spoken,

Source: OECD calculations based on Survey of Adult Skills (PIAAC) (2012).

16. The Survey of Adult skills does not allow studying the effects of work and study on subsequent labour market outcomes (see Box 2 for evidence from the literature) but it does provide unique comparable cross-country information on the incidence and composition of work and study and on the proficiency of youth choosing to combine the two. 


\section{Box 2. Combining study and work: Achieving the right balance}

The impact of combining study and work on future labour market outcomes has been thoroughly studied. The number of hours worked is recognised in most analyses as being the key factor, with positive returns emerging when work is half-time or less. The fact that it provides students with some income is also important, as this may help cover part of the costs of their studies or the cost of living while studying.

\section{Impact of early work experience while in high school}

On the one hand, evidence suggests that early work experience, while enrolled in high school, may hinder school performance, as working students fall behind in their schoolwork to the point where dropping out of school and entering the labour market becomes the preferred option. Working students may also simply lose interest in schoolwork and enter the labour force early on a full-time basis.

On the other hand, some moderate exposure to the labour market via internships, summer jobs or in jobs of no more than 15 hours a week during the school year should not compromise school achievement. It could actually improve teenagers' prospects of graduating from high school, as it might lead them to develop life-skills, such as a greater sense of responsibility, improved work ethics, and better discipline. It might also help teenagers decide what they intend to do later.

Whether high-school employment is beneficial or not has been extensively researched in the United States over the past three decades. While some of the earlier studies (e.g. Greenberger and Steinberg, 1986) tend to find negative impacts, more recent work shows that modest involvement in work activities actually leads to positive outcomes. In particular, Ruhm (1997) finds strong evidence that early work experience leads to higher future wages and better fringe benefits. Additionally, he finds that students working ten hours per week during their senior year have a higher probability of graduating from high school than those who do not work at all, although a heavier work commitment is associated with a lower probability of graduation.

\section{Impact of student jobs while in tertiary education}

In a number of countries, tertiary students work to off-set the costs of their studies. However, it is not the only reason for student work. Countries where student work is very widespread are not necessarily those where tertiary fees are high. In Nordic countries, where all students receive a study allowance and tertiary studies are free, almost all students work to be financially independent and to leave the parental home. By contrast, in France where tertiary fees are low, student work is perceived as a necessity for students not lucky enough to benefit from the financial support of their parents and constitutes a source of additional income on top of public scholarships for young people from disadvantaged backgrounds.

Overall, most analyses provide evidence that working a moderate number of hours helps youth in post-school labour market outcomes without compromising school achievement (Dundes and Marx, 2006).

In some European countries, emphasis is also put on the relation between work content and the student's field of study. Evidence from France (Beffy et al., 2009) shows that work experience acquired while studying has a clear positive effect on future labour market outcomes only if the job is related to the student's field of study.

17. Finally, while it is not possible to explore how the combination of work and study affects labour market outcomes using the Survey of Adult Skills, a higher incidence of work and study appears to be associated with lower unemployment rates among non-studying youth (Figure 10). 
Figure 10. Correlation between the incidence of work and study and youth unemployment ${ }^{a}$

Percentages

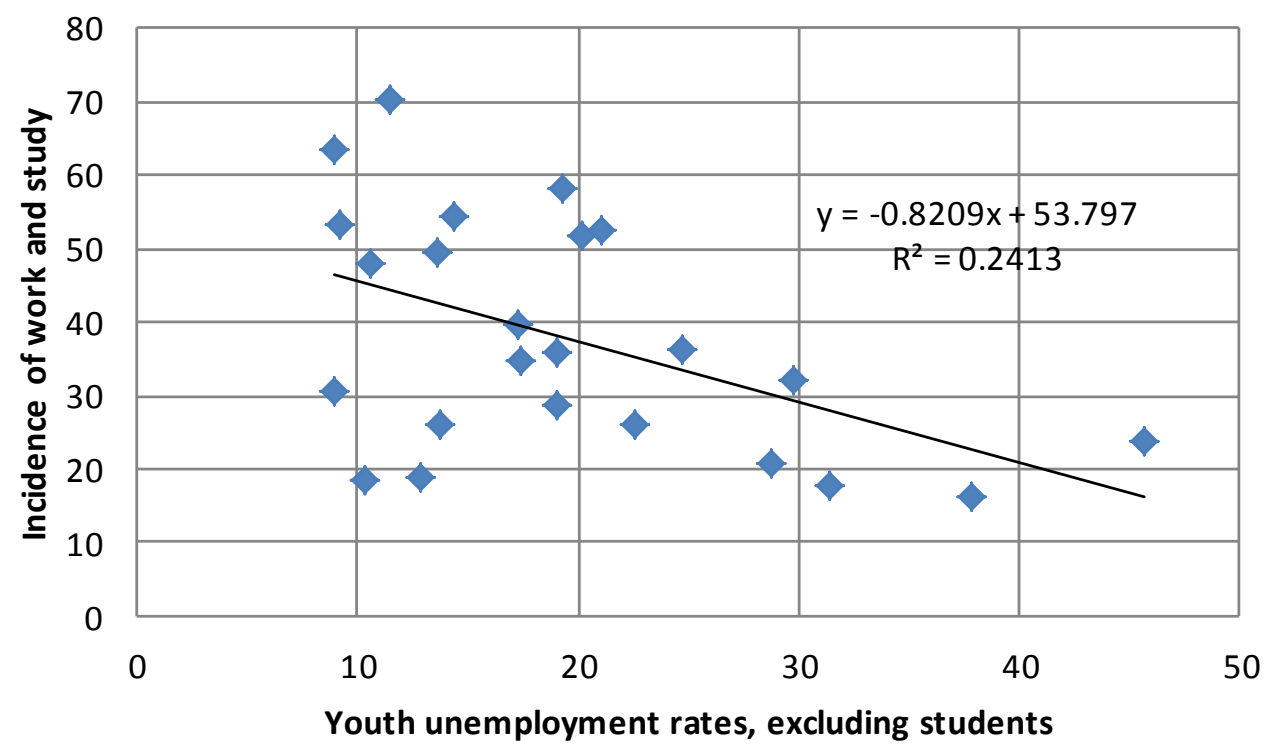

a) The youth unemployment rate has been calculated excluding youth are still studying. Given that students who combine work and study are by definition not unemployed, including them would make the relationship stronger by construction.

Source: OECD calculations based on Survey of Adult Skills (PIAAC) (2012).I

\section{Conclusions}

18. The Survey of Adult Skills (PIAAC) allows drawing a comprehensive picture of work and study, including its composition, its socio-demographic determinants and the nature and content of jobs held by students compared to those held by similar workers.

19. This paper focuses on 23 of the countries/regions participating in the survey. It finds that $39 \%$ of students work on average across these countries, an incidence that ranges from about $15 \%$ in Italy to over $60 \%$ in the Netherlands. While apprenticeship schemes and VET programmes account for up to $50 \%$ of all work-and-study in some countries, the vast majority of students work outside these formalised programmes, many of them in jobs that are not related to their field of study.

20. While critics of work and study highlight the importance of working in one's own field, the paper shows that there is a positive correlation between field of study mismatch among students and field of study mismatch among non-students suggesting that employers in different countries may attach different values to candidates' fields when hiring them. Critics also point to the fact that working students' skills may not be put to appropriate use by employers. The paper finds no evidence of this, showing instead that students use their skills at work in a very similar way as their colleagues, controlling for the number of hours worked and the occupation.

21. More flexible labour markets where hiring and firing are relatively easy and part-time is widespread are found to be more conducive of students' work. The share of public sector employment is also found to be positively related to the likelihood of work and study while a negative correlation is found with the ratio of the minimum-to-median wage in the country which may make it too costly for employers to hire inexperienced students. Another interesting fact is that, despite strong gender stereotyping in some 
VET and apprenticeship programmes, gender does not appear to influence the likelihood of work and study, once other factors are controlled for.

22. Finally, the paper presents how some outcome variables are associated with the probability of work and study. Although reverse causality is a serious issue, it is shown that while VET working students and apprentices tend to have lower scores than non-working students after controlling for other socio-demographic characteristics, the opposite is true for those working outside these formalised programmes. Also, while it is not possible to examine the relationship between work and study and future labour market outcomes at the individual level, a negative correlation between the share of students who work and study and youth unemployment is found. 


\section{BIBLIOGRAPHY}

Beffy, M., D. Fougère and A. Maurel (2009), “L’impact du travail salarié des étudiants sur la réussite et la poursuite des études universitaires", Économie et Statistique, No. 422, Paris.

Dundes, L. and J. Marx (2006), "Balancing Work and Academics in College: Why Do Students Working 10 to 19 Hours per Week Excel?", Journal of College Student Retention: Research, Theory and Practice, Vol. 8, No. 1.

Greenberger, E. and L.D. Steinberg (1986), The Psychological and Social Costs of Adolescent Employment, Basic, New York.

Quintini, G. (2014), "Skills at Work: How Skills and their Use Matter in the Labour Market", OECD Social, Employment and Migration Working Papers, No. 158, OECD Publishing, Paris, http://dx.doi.org/10.1787/5jz44fdfjm7j-en.

Ruhm, C.J. (1997), “Is High School Employment Consumption or Investment?”, Journal of Labor Economics, No. 15.

Wolbers, M. (2003), "Job mismatches and their labour market effects among school-leavers in Europe" European Sociological Review, Vol. 19, pp. 249-266. 


\section{ANNEX A.1. CODING OF ISCO-08 3-DIGIT OCCUPATION CLASSIFICATION TO FIELDS FOR FIELD-OF-STUDY MISMATCH}

The following correspondence defines well matched individuals based on their field-of-study (in italics) and ISCO-08 occupation. The same correspondence table categorises occupations into occupational groups.

- (2) Teacher training and education science: university, higher education, vocational, secondary, primary, early childhood and other teaching professionals (ISCO 231-235); sports and fitness workers (ISCO 342); and child care workers and teaches' aides (ISCO 531).

- (3) Humanities, languages and arts: university, higher education, vocational and secondary education teaching professionals (ISCO 231-233); architects, planners, surveyors and designers (ISCO 216); librarians, archivists and curators (ISCO 262); social and religious professionals (ISCO 263); authors, journalists and linguists (ISCO 264); creative and performance artists (ISCO 265); legal, social and religious associate professionals (ISCO 341); and artistic, cultural and culinary associate professionals (ISCO 343).

- (4) Social sciences, business and law: directors and chief executives (ISCO 112), managers (ISCO 121-122, 131-134, 141-143); university, vocational and secondary education teaching professionals (ISCO 231-233); business and administration professionals (ISCO 241-243); other health professionals (ISCO 226); legal professionals (ISCO 261); librarians, archivists and curators (ISCO 262); social and religious professionals (ISCO 263); authors, journalists and linguists (ISCO 264); business and administration associate professionals (ISCO 331-335); other health associate professionals (ISCO 325); legal, social and religious associate professionals (ISCO 341); clerical support workers (ISCO 411-413, 421-422, 431-432, 441); sales workers (ISCO 521-524); and street vendors (excluding food) (ISCO 952).

- (5) Science, mathematics and computing: physical and earth science professionals (ISCO 211); mathematicians, actuaries and statisticians (ISCO 212); life science professionals (ISCO 213); other health professionals (ISCO 226); university, vocational and secondary education teaching professionals (ISCO 231-233); Information and communications technology professionals (ISCO 251-252); physical and engineering science technicians (ISCO 311); process control technicians (ISCO 313); life science technicians and related associate professionals (ISCO 314); medical and pharmaceutical technicians (ISCO 321); financial and mathematical associate professionals (ISCO 331); information and communications technicians (ISCO 351-352).

- (6) Engineering, manufacturing and construction: engineering professionals (ISCO 214); electrotechnology engineers (ISCO 215); architects, planners, surveyors and designers (ISCO 216); university, higher education and vocational education teaching professionals (ISCO 231-232); information and communications technology professionals (ISCO 251-252); physical and engineering science technicians (ISCO 311); mining, manufacturing and construction supervisors (ISCO 312); process control technicians (ISCO 313); ship and aircraft controllers and technicians (ISCO 315); regulatory government associate professionals (ISCO 335); information and communications technicians (ISCO 351-352); building and housekeeping supervisors (ISCO 515); crafts and related trades workers (ISCO 711-713, 721-723, 731-732, 741-742, 751-754); plant and machine operators and assemblers (ISCO 811-818, 821, 831-835); and labourers in mining, construction, manufacturing and transport (ISCO 931-933). 
- (7) Agriculture and veterinary: life science professionals (ISCO 213); veterinarians (ISCO 225); university, higher education and vocational education teaching professionals (ISCO 231-232); life science technicians and related associate professionals (ISCO 314); medical and pharmaceutical technicians (ISCO 321); veterinary technicians and assistants (ISCO 324); other health associate professionals (ISCO 325); skilled agricultural, forestry and fishery workers (ISCO 611-613, 621-622, 631-634); food processing and related trades workers (ISCO 751); other craft and related workers (ISCO 754); mobile plant operators (ISCO 834); and agricultural, forestry and fishery labourers (ISCO 921);

- (8) Health and welfare: life science professionals (ISCO 213), health professionals (ISCO 221-227); university and higher education teaching professionals (ISCO 231); primary school and early childhood teachers (ISCO 234); social and religious professionals (ISCO 263); health associate professionals (ISCO 321-325); legal, social and religious associate professionals (ISCO 341); other personal service workers (ISCO 516); personal care workers (ISCO 531-532); and protective services workers (ISCO 541).

- (9) Service: professional services managers (ISCO 134); sales, marketing and public relations professionals (ISCO 243); other health associate professionals (ISCO 325); administrative and specialised secretaries (ISCO 334); regulatory government associate professionals (ISCO 335); legal, social and religious associate professionals (ISCO 341); artistic, cultural and culinary associate professionals (ISCO 343); clerical support workers (ISCO 411-413, 421-422, 431-432, 441); service and sales workers (ISCO 511-516, 521-524, 531-532, 541); drivers and mobile plant operators (ISCO 831-835); cleaners and helpers (ISCO 911-912); food preparation assistants (ISCO 941); street and related service workers (ISCO 951); and street vendors (excluding food) (ISCO 952).

- Coded as missing: all self-employed workers and those who majored in "general programmes"; armed forces occupations (ISCO major group 0); legislators and senior officials (ISCO 111); and refuse workers and other elementary workers (ISCO 961-962). 


\section{OECD SOCIAL, EMPLOYMENT AND MIGRATION WORKING PAPERS}

Most recent releases are:

No. 168 THE EFFECTS OF VOCATIONAL EDUCATION ON ADULT SKILLS AND WAGES. WHAT CAN WE LEARN FROM PIAAC?, Giorgio Brunello and Lorenzo Rocco (2015)

No. 167 THE CAUSES AND CONSEQUENCES OF FIELD-OF-STUDY MISMATCH: AN ANALYSIS USING PIAAC, Guillermo Montt (2015)

No. 166 HOW DEMANDING ARE ELIGIBILITY CIRTERIA FOR UNEMPLOYMENT BENEFITS, QUANTITATIVE INDICATORS FOR OECD AND EU COUNTRIES, Kristine Langenbucher (2015)

No. 165 LOST AND FOUND? THE COST OF JOB LOSS IN FRANCE, Vahé Nafilyan (2015)

No. 164 NEET YOUTH IN THE AFTERMATH OF THE CRISIS: CHALLENGES AND POLICIES, Stéphane Carcillo, Rodrigo Fernández and Sebastian Königs, OECD Directorate for Employment, Labour and Social Affairs, Social Policy Division; Andreea Minea, Sciences Po Paris (2015)

No. 163 TRENDS IN INCOME INEQUALITY AND ITS IMPACT ON ECONOMIC GROWTH, Federico Cingano (Forthcoming)

No. 162 ARE RECIPIENTS OF SOCIAL ASSISTANCE 'BENEFIT DEPENDENT'? CONCEPTS, MEASUREMENT AND RESULTS FOR SELECTED COUNTRIES, Herwig Immervoll, Stephen P. Jenkins, Sebastian Königs (2014)

No. 161 MENTAL HEALTH AND WORK: ACHIEVING WELL-INTEGRATED POLICIES AND SERVICE DELIVERY, Iris Arends, Niklas Baer, Veerle Miranda, Christopher Prinz and Shruti Singh (2014)

No. 160 A NEW PROFILE OF MIGRANTS IN THE AFTERMATH OF THE RECENT ECONOMIC CRISIS, Cansin Arslan, Jean-Christophe Dumont, Zovanga Kone, Yasser Moullan, Caglar Ozden, Christopher Parsons, Theodora Xenogiani (2014)

No. 159 TRENDS IN TOP INCOMES AND THEIR TAXATION IN OECD COUNTRIES, Michael Förster, Ana Llena-Nozal and Vahé Nafilyan (2014)

No. 158 SKILLS AT WORK: HOW SKILLS AND THEIR USE MATTER IN THE LABOUR MARKET, Glenda Quintini (2014)

No. 157 CHANGES IN FAMILY POLICIES AND OUTCOMES: IS THERE CONVERGENCE?, Willem Adema, Nabil Ali, and Oliver Thévenon

No. 156 RETOUR À L'EMPLOI DES CHOMEURS SENIORS FRANÇAIS AYANT BENEFICIE D'UN ACCOMPAGNEMENT RENFORCE VERS L'EMPLOI EN 2009 ET 2010, Gwenn Parent (2014)

No. 155 MIGRATION AS AN ADJUSTMENT MECHANISM IN THE CRISIS? A COMPARISON OF EUROPE AND THE UNITED STATES, Julia Jauer, Thomas Liebig, John P. Martin and Patrick Puhani (2014)

No. 154 SAME BUT DIFFERENT: SCHOOL-TO-WORK TRANSITIONS IN EMERGING AND ADVANCED ECONOMIES, Glenda Quintini and Sébastien Martin (2014)

No. 153 A NEW MEASURE OF SKILLS MISMATCH, Michele Pellizzari and Anne Fichen (2013)

No. 152 CATASTROPHIC JOB DESTRUCTION, Anabela Carneiro, Pedro Portugal and José Varejão (2013)

No. 151 THE PERVERSE EFFECTS OF JOB-SECURITY PROVISIONS ON JOB SECURITY IN ITALY: RESULTS FROM A REGRESSION DISCONTINUITY DESIGN, Alexander Hijzen, Leopoldo Mondauto, Stefano Scarpetta (2013)

No. 150 REDISTRIBUTION POLICY IN EUROPE AND THE UNITED STATES: IS THE GREAT RECESSION A 'GAME CHANGER' FOR WORKING-AGE FAMILIES? Herwig Immervoll, Linda Richardson (2013)

No. 149 A BIRD'S EYE VIEW OF GENDER DIFFERENCES IN EDUCATION IN OECD COUNTRIES Angelica Salvi Del Pero and Alexandra Bytchkova (2013)

No. 148 TRENDS IN POVERTY AND INEQUALITY IN DECENTRALISING INDONESIA Riyana Miranti, Yogi Vidyattama, Erick Hansnata, Rebecca Cassells and Alan Duncan (2013) 
No. 147 WOMEN ENTREPRENEURS IN THE OECD: KEY EVIDENCE AND POLICY CHALLENGES Mario Piacentini (2013)

No. 146 AN EVALUATION OF INTERNATIONAL SURVEYS OF CHILDREN, Dominic Richardson and Nabil Ali (2014)

No. 145 DRIVERS OF FEMALE LABOUR FORCE PARTICIPATION IN THE OECD Olivier Thévenon (2013)

No. 144 THE ROLE OF SHORT-TIME WORKING SCHEMES DURING THE GLOBAL FINANCIAL CRISIS AND EARLY RECOVERY, Alexander Hijzen, Sébastien Martin (2012)

No. 143 TRENDS IN JOB SKILL DEMANDS IN OECD COUNTRIES, Michael J. Handel (2012)

No. 142 HELPING DISPLACED WORKERS BACK INTO JOBS AFTER A NATURAL DISASTER: RECENT EXPERIENCES IN OECD COUNTRIES, Danielle Venn (2012)

No. 141 LABOUR MARKET EFFECTS OF PARENTAL LEAVE POLICIES IN OECD COUNTRIES, Olivier Thévenon \& Anne Solaz (2012)

No. 140 FATHERS' LEAVE, FATHERS' INVOLVEMENT AND CHILD DEVELOPMENT: ARE THEY RELATED? EVIDENCE FROM FOUR OECD COUNTRIES, Maria C. Huerta, Willem Adema, Jennifer Baxter, WenJui Han, Mette Lausten, RaeHyuck Lee and Jane Waldfogel (2012)

No. 139 FLEXICURITY AND THE ECONOMIC CRISIS 2008-9 - EVIDENCE FROM DENMARK, Tor Eriksson (2012)

No. 138 EFFECTS OF REDUCING GENDER GAPS IN EDUCATION AND LABOUR FORCE PARTICIPATION ON ECONOMIC GROWTH IN THE OECD, Olivier Thévenon, Nabil Ali, Willem Adema and Angelica Salvi del Pero (2012)

No. 137 THE RESPONSE OF GERMAN ESTABLISHMENTS TO THE 2008-2009 ECONOMIC CRISIS, Lutz Bellman, Hans-Dieter Gerner, Richard Upward (2012)

No. 136 Forthcoming THE DYNAMICS OF SOCIAL ASSISTANCE RECEIPT IN GERMANY Sebastian Königs

No. 135 MONEY OR KINDERGARTEN? DISTRIBUTIVE EFFECTS OF CASH VERSUS IN-KIND FAMILY TRANSFERS FOR YOUNG CHILDREN, Michael Förster and Gerlinde Verbist (2012)

No. 134 THE ROLE OF INSTITUTIONS AND FIRM HETEROGENEITY FOR LABOUR MARKET ADJUSTMENTS: CROSS-COUNTRY FIRM-LEVEL EVIDENCE, Peter N. Gal (VU University Amsterdam), Alexander Hijzen and Zoltan Wolf (2012)

No. 133 CAPITAL'S GRABBING HAND? A CROSS-COUNTRY/CROSS-INDUSTRY ANALYSIS OF THE DECLINE OF THE LABOUR SHARE, Andrea Bassanini and Thomas Manfredi (2012)

No. 132 INCOME DISTRIBUTION AND POVERTY IN RUSSIA, Irinia Denisova (2012)

No. 131 ELIGIBILITY CRITERIA FOR UNEMPLOYMENT BENEFITS, Danielle Venn (2012)

No. 130 THE IMPACT OF PUBLICLY PROVIDED SERVICES ON THE DISTRIBUTION OF RESOURCES: REVIEW OF NEW RESULTS AND METHODS, Gerlinde Verbist, Michael Förster and Maria Vaalavuo (2012)

No. 129 AN OVERVIEW OF AUSTRALIA'S SYSSTEM OF INCOME AND EMPLOYMENT ASSISTANCE FOR THE UNEMPLOYED, Peter Davidson, Peter Whiteford (2012)

No. 128 THE INTEGRATION OF IMMIGRANTS AND THEIR CHILDREN INTO THE LABOUR MARKET IN SWITZERLAND, Thomas Liebig, Sebastian Kohls and Karoline Krause (2012)

No. 127 THE LABOUR MARKET INTEGRATION OF IMMIGRANTS AND THEIR CHILDREN IN AUSTRIA, Karolin Krause and Thomas Liebig (2011)

No. 126 ARE RECENT IMMIGRANTS DIFFERENT? A NEW PROFILE OF IMMIGRANTS IN THE OECD BASED ON DIOC 2005/06, Sarah Widmaier and Jean-Christophe Dumont (2011)

No. 125 EARNINGS VOLATILITY AND ITS CONSEQUENCES FOR HOUSEHOLDS, Danielle Venn (2011) 
No. 124 CRISIS, RECESSION AND THE WELFARE STATE, Willem Adema, Pauline Fron and Maxime Ladaique (2011)

No. 123 AGGREGATE EARNINGS AND MACROECONOMIC SHOCKS Andrea Bassanini (2011)

No. 122 REDISTRIBUTION POLICY AND INEQUALITY REDUCTION IN OECD COUNTRIES: WHAT HAS CHANGED IN TWO DECADES? Herwig Immervoll, Linda Richardson (2011)

No. 121 OVER-QUALIFIED OR UNDER-SKILLED, Glenda Quintini (2011)

No. 120 RIGHT FOR THE JOB, Glenda Quintini (2011)

No. 119 THE LABOUR MARKET EFFECTS OF UNEMPLOYMENT COMPENSATION IN BRAZIL, Alexander Hijzen (2011)

No. 118 EARLY MATERNAL EMPLOYMENT AND CHILD DEVELOPMENT IN FIVE OECD COUNTRIES, Maria del Carmen Huerta, Willem Adema, Jennifer Baxter, Miles Corak, Mette Deding, Matthew C. Gray, Wen-Jui Han, Jane Waldfogel (2011)

No. 117 WHAT DRIVES INFLOWS INTO DISABILITY?EVIDENCE FROM THREE OECD COUNTRIES Ana Llena-Nozal and Theodora Xenogiani (2011)

No. 116 COOKING, CARING AND VOLUNTEERING: UNPAID WORK AROUND THE WORLD, Veerle Miranda (2011)

No. 115 THE ROLE OF SHORT-TIME WORK SCHEMES DURING THE 2008-09 RECESSION, Alexander Hijzen and Danielle Venn (2010)

No. 114 INTERNATIONAL MIGRANTS IN DEVELOPED, EMERGING AND DEVELOPING COUNTRIES: AN EXTENDED PROFILE,

Jean-Christophe Dumont, Gilles Spielvogel and Sarah Widmaier (2010)

No. 113 ACTIVATION POLICIES IN JAPAN, Nicola Duell, David Grubb, Shruti Singh and Peter Tergeist (2010)

No. 112 ACTIVATION POLICIES IN SWITZERLAND, Nicola Duell and Peter Tergeist with contributions from Ursula Bazant and Sylvie Cimper (2010)

No. 111 ECONOMIC DETERMINANTS AND CONSEQUENCES OF CHILD MALTREATMENT Lawrence M. Berger, Jane Waldfogel (forthcoming)

No. 110 DISTRIBUTIONAL CONSEQUENCES OF LABOR DEMAND ADJUSTMENTS TO A DOWNTURN: A MODEL-BASED APPROACH WITH APPLICATION TO GERMANY 2008-09, Herwig Immervoll, Olivier Bargain, Andreas Peichl, Sebastian Siegloch (2010)

No. 109 DECOMPOSING NOTIONAL DEFINED-CONTRIBUTION PENSIONS: EXPERIENCE OF OECD COUNTRIES' REFORMS, Edward Whitehouse (2010)

No. 108 EARNINGS OF MEN AND WOMEN WORKING IN THE PRIVATE SECTOR: ENRICHED DATA FOR PENSIONS AND TAX-BENEFIT MODELING, Anna Cristina D'Addio and Herwig Immervoll (2010)

No. 107 INSTITUTIONAL DETERMINANTS OF WORKER FLOWS: A CROSS-COUNTRY/CROSS-INDUSTRY APPROACH, Andrea Bassanini, Andrea Garnero, Pascal Marianna, Sebastien Martin (2010)

No. 106 RISING YOUTH UNEMPLOYMENT DURING THE CRISIS: HOW TO PREVENT NEGATIVE LONG-TERM CONSEQUENCES ON A GENERATION?

Stefano Scarpetta, Anne Sonnet and Thomas Manfredi (2010)

No. 105 TRENDS IN PENSION ELIGIBILITY AGES AND LIVE EXPECTANCY, 1950-2050 Rafal Chomik and Edward Whitehouse (2010)

No. 104 ISRAELI CHILD POLICY AND OUTCOMES John Gal, Mimi Ajzenstadt, Asher Ben-Arieh, Roni Holler and Nadine Zielinsky (2010)

No. 103 REFORMING POLICIES ON FOREIGN WORKERS IN ISRAEL Adriana Kemp (2010) 
No. 102 LABOUR MARKET AND SOCIO-ECONOMIC OUTCOMES OF THE ARAB-ISRAELI POPULATION Jack Habib, Judith King, Asaf Ben Shoham, Abraham Wolde-Tsadick and Karen Lasky (2010)

No. 101 TRENDS IN SOUTH AFRICAN INCOME DISTRIBUTION AND POVERTY SINCE THE FALL OF APARTHEID

Murray Leibbrandt, Ingrid Woolard, Arden Finn and Jonathan Argent (2010)

No. 100 MINIMUM-INCOME BENEFITS IN OECD COUNTRIES: POLICY DESIGN, EFFECTIVENESS AND CHALLENGES

Herwig Immervoll (2009)

A full list of Social, Employment and Migration Working Papers is available at www.oecd.org/els/workingpapers.

Other series of working papers available from the OECD include: $\underline{\text { OECD Health Working Papers. }}$ 


\section{RECENT RELATED OECD PUBLICATIONS:}

EMPLOYMENT OUTLOOK 2015, http://www.oecd.org/employment/oecdemploymentoutlook.htm

MENTAL HEALTH AND WORK: NETHERLANDS, http://www.oecd.org/netherlands/mental-health-and-worknetherlands-9789264223301-en.htm

MATCHING ECONOMIC MIGRATION WITH LABOUR MARKET NEEDS, http://www.oecd.org/eu/matching-economicmigration-with-labour-market-needs.htm

EMPLOYMENT OUTLOOK 2014, http://www.oecd.org/employment/oecdemploymentoutlook.htm

CONNECTING PEOPLE WITH JOBS UK,

http://www.oecd.org/employment/emp/activelabourmarketpoliciesandactivationstrategies.htm

RECRUITING IMMIGRANT WORKERS NEW ZEALAND, http://www.oecd.org/migration/recruiting-immigrant-workers$\underline{n z-2014 . h t m}$

JOBS FOR IMMIGRANTS VOL. 4 ITALY, http://www.oecd.org/els/jobsforimmigrantsseries.htm

THE 2012 LABOUR MARKET REFORM IN SPAIN, http://www.oecd.org/employment/spain-labourmarketreform.htm

INVESTING IN YOUTH: BRAZIL (2014), www.oecd.org/employment/action-plan-youth.htm

AGEING AND EMPLOYMENT POLICIES: NETHERLANDS 2014, http://www.oecd.org/els/ageing-and-employmentpolicies-netherlands-2014-9789264208155-en.htm

OECD REVIEWS OF PENSION SYSTEMS: IRELAND, http://www.oecd.org/els/public-pensions/reforms-essential-tomake-irelands-pensionsystem-fairer.htm

AGEING AND EMPLOYMENT POLICIES: NETHLERLANDS 2014, www.oecd.org/els/employment/olderworkers

SOCIETY AT A GLANCE 2014, www.oecd.org/els/societyataglance.htm

MENTAL HEALTH AND WORK: UNITED KINGDOM (2014), www.oecd.org/els/emp/mentalhealthandworkunitedkingdom.htm

VIEILLISSEMENT ET POLITIQUES DE L'EMPLOI : FRANCE 2014: MIEUX TRAVAILLER AVEC L'ÂGE, www.oecd.org/frlemploi/emp/vieillissementetpolitiquesdelemploi.htm

MENTAL HEALTH AND WORK: SWITZERLAND (2014), www.oecd.org/els/emp/mentalhealthandwork-switzerland.htm

PENSIONS AT A GLANCE 2013, www.oecd.org/els/public-pensions/pensionsataglance.htm

HEALTH AT A GLANCE 2013: OECD INDICATORS, www.oecd.org/health/health-systems/health-at-a-glance.htm

OECD EMPLOYMENT OUTLOOK 2013, www.oecd.org/els/emp/oecdemploymentoutlook.htm

CLOSING THE GENDER GAP: ACT NOW, www.oecd.org/gender/closingthegap.htm

OECD PENSIONS OUTLOOK 2012, www.oecd.org/finance/privatepensions/

INTERNATIONAL MIGRATION OUTLOOK 2012, www.oecd.org/els/internationalmigrationpoliciesanddatal

OECD EMPLOYMENT OUTLOOK 2012, www.oecd.org/employment/employmentpoliciesanddata

SICK ON THE JOB: Myths and Realities about Mental Health and Work (2011), www.oecd.org/els/disability

DIVIDED WE STAND: Why Inequality Keeps Rising (2011), www.oecd.org/els/social/inequality

EQUAL OPPORTUNITIES? The Labour Market Integration of the Children of Immigrants (2010), via OECD Bookshop 
OECD REVIEWS OF LABOUR MARKET AND SOCIAL POLICIES: ESTONIA (2010), www.oecd.org/els/estonia2010 JOBS FOR YOUTH: GREECE (2010), www.oecd.org/employment/youth

JOBS FOR YOUTH: DENMARK (2010), www.oecd.org/employment/youth

OECD REVIEWS OF LABOUR MARKET AND SOCIAL POLICIES: ISRAEL (2010), www.oecd.org/els/israel2010

JOBS FOR YOUTH: UNITED STATES (2009), www.oecd.org/employment/youth

JOBS FOR YOUTH: POLAND (2009), www.oecd.org/employment/youth

OECD EMPLOYMENT OUTLOOK: Tackling the Jobs Crisis (2009), www.oecd.org/els/employmentpoliciesanddata/ DOING BETTER FOR CHILDREN (2009), www.oecd.org/els/social/childwellbeing

SOCIETY AT A GLANCE - ASIA/PACIFIC EDITION (2009), www.oecd.org/els/social/indicators/asia OECD REVIEWS OF LABOUR MARKET AND SOCIAL POLICIES: SLOVENIA (2009), www.oecd.org/els/slovenia2009 INTERNATIONAL MIGRATION OUTLOOK: SOPEMI (2010) www.oecd.org/els/migration/imo

PENSIONS AT A GLANCE 2009: Retirement-Income Systems in OECD Countries (2009), www.oecd.org/els/social/pensions/PAG

JOBS FOR YOUTH: FRANCE (2009), www.oecd.org/employment/youth

SOCIETY AT A GLANCE 2009 - OECD Social Indicators (2009), www.oecd.org/els/social/indicators/SAG

JOBS FOR YOUTH: AUSTRALIA (2009), www.oecd.org/employment/youth

OECD REVIEWS OF LABOUR MARKET AND SOCIAL POLICIES: CHILE (2009), www.oecd.org/els/chile2009

PENSIONS AT A GLANCE - SPECIAL EDITION: ASIA/PACIFIC (2009),www.oecd.org/els/social/pensions/PAG

SICKNESS, DISABILITY AND WORK: BREAKING THE BARRIERS (VOL. 3) - DENMARK, FINLAND, IRELAND AND THE NETHERLANDS (2008), www.oecd.org/els/disability

GROWING UNEQUAL? Income Distribution and Poverty in OECD Countries (2008), www.oecd.org/els/social/inequality JOBS FOR YOUTH: JAPAN (2008), www.oecd.org/employment/youth JOBS FOR YOUTH: NORWAY (2008), www.oecd.org/employment/youth JOBS FOR YOUTH: UNITED KINGDOM (2008), www.oecd.org/employment/youth JOBS FOR YOUTH: CANADA (2008), www.oecd.org/employment/youth JOBS FOR YOUTH: NEW ZEALAND (2008), www.oecd.org/employment/youth JOBS FOR YOUTH: NETHERLANDS (2008), www.oecd.org/employment/youth For a full list, consult the OECD online Bookshop at www.oecd.org/bookshop 